\title{
Consensus of Democracy in Making The National Development (Case Study of Dynamics Conflict of Selection of The Message Village Head in Blitar District)
}

\author{
Anwar Samaudin ${ }^{(1)}$ \\ ${ }^{1}$ Universitas Brawijaya Malang \\ E-mail: ${ }^{1}$ iswatinhasanah122@yahoo.com
}

Received: 15 May 2018; Revised: 16 May 2018; Accepted: 16 May 2018

\begin{abstract}
Abstrack
This research is based on the simultaneous election of village heads in 2013. This phenomenon arises because of the local government policy to hold simultaneous village head elections in Blitar regency. This study aims to determine the description of conflict of simultaneous village head election in Blitar Regency followed by 150 villages. This research was conducted in eight villages of Blitar Regency. This research uses qualitative method, and described descriptively with data source in this research consist of 8 candidate of village head, some support from eight candidate of village head who has conflict. Data collection techniques used are observation, interview and documentation. Sampling technique used in this research is purposive sampling. The validity of the data in this study using triangulation techniques sources and data analysis using interactive Miles and Huberman. The result of the research shows that the conflict of simultaneous village head election in Blitar Regency that varied from the couple of husband and wife, the candidate pair from the messenger or the right hand of one candidate, the existence of some cheating in the election process, the candidate of the headache is sick to death, self. The conflicts are caused by several factors such as the absence of the candidates who register until the time limit is set, the public expectation of the leadership of one of the candidates, and the simultaneous village head election conflict in Blitar Regency are ridden by other interests, there are those who do not like one of the candidates village head. Forms of conflict that occurred in Blitar district that is the latent conflict that already exists between the two candidates for village head, manifest conflict is a riot in the form of filing a lawsuit, there is also a vertical conflict between one candidate with the supporters of the opposing party and also horizontal conflict that is between supporters.
\end{abstract}

Key words: job title, conflict, village head election,

\section{Introduction}

Implementation of democracy in Indonesia based on law, then the 1945 Constitution improved. The direct election system is believed to increase the level of democracy, transparency and the election of figures capable of running the government and prospering the people (Any
Rohayati, 2006: 81-82). The election of the village head is a rural democratic practice involving the legitimacy of power and the aspect of power determination, thus inviting competition to win the post of village head. The struggle for the position of the village head is in need of active participation from the community which is an obligation on the community itself in the 
election of the village head (Purba Sari, 2011). The election of the village head is a real democracy event, because it deals directly with the community and the candidates are well known to the public. The election of the village head is a place to accommodate the political aspirations of the community, of course, the elected village chief is able to meet the people's expectations. The election of village heads was arranged in Law No. 32 of 2004, but in practice the election of village heads was colored by conflicts both in individual conflicts and in group conflicts. In a social organization will occur relationships or interactions among members. The aggressive nature or animal power that exists in humans causes problems, so that a person or a group of people will simply take away the property or other person's business results unlawfully. For someone who faces such a condition, where his property is deprived, of course, will take the fight to block the action. Thus, there was a dispute that led to hostilities and even bloodshed (Affandi, 2004: 94). Actually the conflict cannot be separated from human life especially in power struggles because basically everyone has a different perspective or view of life and the problems and interests it has. Not that we should stay silent, but on the contrary, all elements of society must participate in minimizing potential conflict potential in the village head elections so as not to undermine democracy and disrupt the process of strengthening democracy at the local and national levels. Conflict will grow longer if one of the unelected candidates keeps the disappointment that is so difficult because in the election process there is an awkwardness both done by the village head election committee and by the candidate who happened to be elected, so can do various ways to protest. The rampant disputes over village head elections to gain power, not accepting defeat by committing disrespectful acts make the government paralyzed, and harming people's rights in obtaining services only because of the interests and egos of a few. In Blitar District, there have been conflicts from the election of village chiefs, among others, in eight villages.

In 2013, Blitar district conducted simultaneous village head elections, not least in eight Dermojayan villages, Kendalrejo, Gadungan, Kotes, Sambigede, Kaulon, Gaprang and Semen villages. The election of village heads in the eight villages was tinged with conflict. Variable conflicts include: (1) Candidates are only one to the end of registration, eventually registering as a competitor. (2) Three villages resigned, one of the candidates sick to death, eventually the competitor who is a married couple also resigned. (3) The candidate is not elected to object and filed a lawsuit to the court. (4) Supporters create a sensation by releasing fish that amounts to hundreds of quintals in rivers that affect people to choose fish hunts from village head election. (5) The dawn attack by handing out money to the public in secret to choose one of the candidates.

\section{Material and Methods \\ Research methods}

This research uses descriptive qualitative research method.

\section{Time and Place of Study}

The study was conducted from January to February 2016. In the data collection, the researcher conducted an interview in Blitar Regency with eight informants.

\section{Informant Selection Technique}

In this study, researchers selected informants by using purposive sampling technique.

\section{Data collection technique}

Data collection techniques conducted in this study is by interview and observation. The researcher observed or observed directly to Blitar Regency, especially eight villages as research location.

\section{Research Processes and Strategies}

The research processes and strategies are carried out in seven consecutive terms according to Creswell's proposals: locating sites, gaining access and making agreements, determining informants (purposefully), collecting data (collecting data), recording, sorting data (resolving field), data analysis (storing data).

\section{Data Validity}

In examining the validity of the data, the researcher did so by triangulating the source by comparing the statements of one informant with another informant. The researcher also compared 


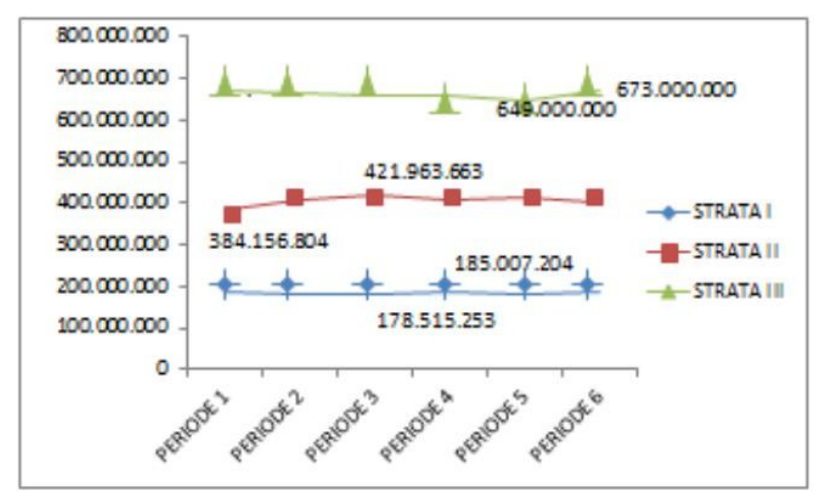

Figure 2 Revenue over periode

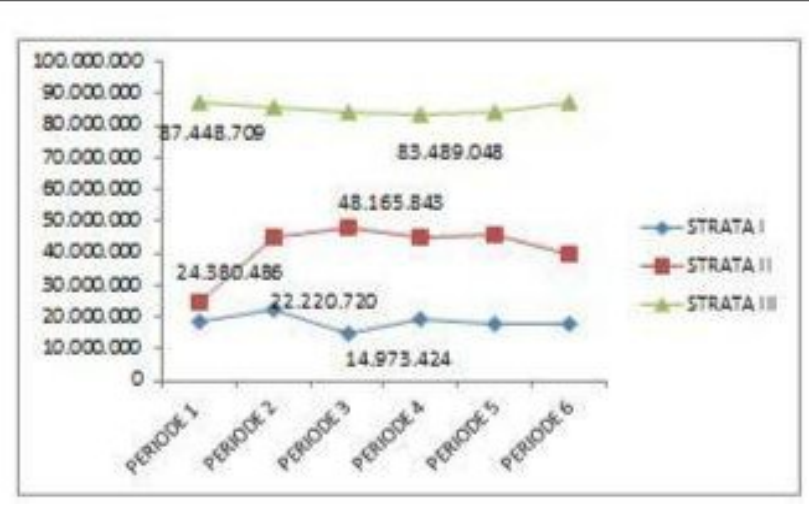

Figure 3 Profit over periode

the informants' own words to the public.

\section{Data analysis technique}

Data analysis techniques in this study were conducted interactively as proposed by Milles and Huberman consisting of three aspects: Data Reduction (Data Reduction), Data Presentation (Data Display), Conclusions Drawing (Verification).

\section{Results and Discussion Conflict Selection of Village Head in Blitar District}

Dahrendorf's conflict theory says that the difference in the distribution of authority is always the factor determining the systematic social conflict, so that certain positions within society delegate power and authority to other positions (Ritzer: 2014). Dahrendorf acknowledged that society would not exist without the conflict and consensus being the requirements of each other. The election of village heads simultaneously presented a plan for the position of the elected village chief together 153, but the one who could carry out the village head election was only 150.

Conflict theory sees that society has two faces (conflict and consensus), therefore sociological theory is divided into two parts: Conflict theory and consensus theory (George Ritzer: 2014). The Conflict Theory has to test the interests and use of violence that binds society to the pressures while consensus theory has to test the integration value in society.

For many Indonesian people, Democracy is identical to the general election, for them the elections are a democracy site, an event to elect their representatives who will fight for the their aspirations in the government, fight for their welfare, fight for a better, safe, comfortable, orderly and peaceful life (Hendrastomo, 2009: 2). By conducting a democratic system, the community hopes that the elected leaders are able to realize

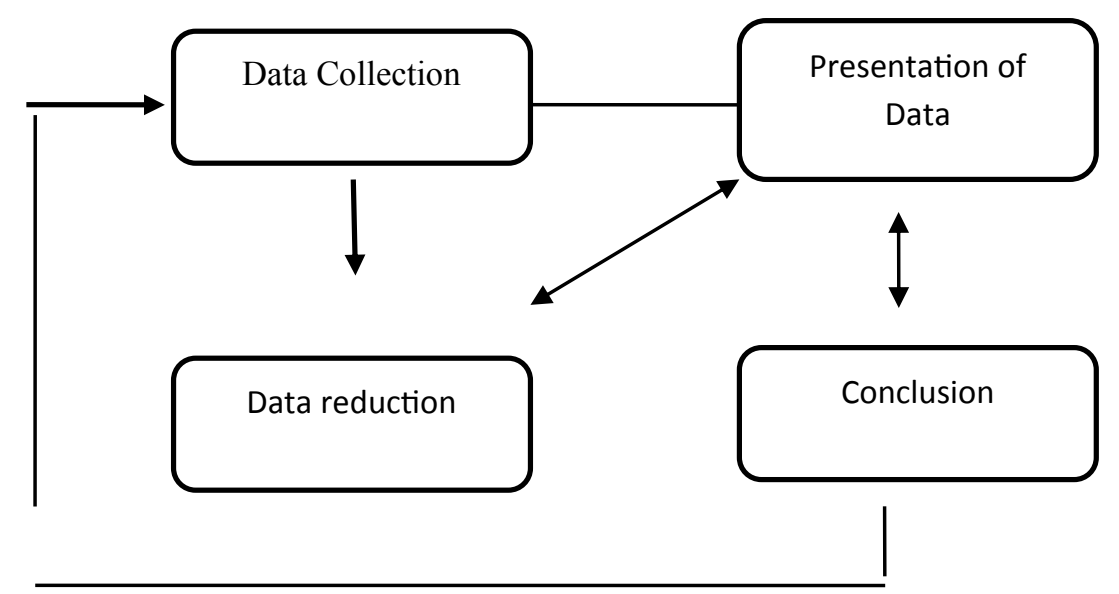

Figure 1 Factors influencing the revenue 
their aspirations, carrying the mandate as a leader. In Blitar District, by village head election, it is expected that the elected one can build a better and more developed village.

\section{Description of the Election Implementa- tion Simultaneous election of Village Head in Blitar District}

The election of village heads is regulated in Law No. 32 of 2004 article 203, that is: "Village head elected directly by villagers from eligible candidates". Candidates for elected village heads with the highest number of votes, as referred to in paragraph (2), are stipulated by the House of Village Representative and authorized by regent (Ani, 2012). Implementation of simultaneous village head elections is an election for Village Governments conducted jointly. Relative election can be done easily, because in a very simple social life, which is still relatively closed to outsiders, people who possess the skills, intellect and character more than others are easily known by the public (Latief 2000: 153). The simultaneous election of village heads in Blitar district started from the preparation stage of August 2013 in the form of socialization to the community in each village regarding to the election of village head and candidates, as well as preparations from the committee. Next from 8 to 11 October 2013 is the time of the campaign, the campaign is done by the candidates by visiting the houses of citizens, public speeches in front of the public to deliver his visions. Voting conducted on October 27 at Village Hall or the residents' home yard as a TPS (vote place), lasted from 07:00 to 15:00 pm. Simultaneous village head elections in Blitar district followed by two or more candidates in each village. In the election this time won by one who gets the highest votes.

\section{Conflict Portrait}

According to Webster (1996), the term conflict in the original language means fight, battle, or struggle that is a physical confrontation between some parties (in Pruitt and Rubin, 2011: 9). Conflict is defined as a direct and based conflict between individuals or groups to achieve the same goal. Dahrendorf (Poloma, 2003: 136). Empirically, group clashes may be easiest to analyze when viewed as contradictory about the legitimacy of power relations. In every association, the interests of dominat group are values that are the ideology of the legitimacy of its power, while the interests of the lower group bear a threat to this ideology and the social relationships in it. Dahrendorf identifies latent interests and real interests, and consciously or unconsciously interests. The connection between these two concepts is a major problematic for conflict theory. The relationship between these two concepts is a major problem for conflict theory. Dahrendorf suggests three types of groups: quasigroups, interest groups, and conflict groups. Dahrendorf felt that, under ideal conditions, conflicts could be explained without reference to other variables. The authority in each association is dichotomous: there are only two sets of conflicts that can form within each association. Groups that hold positions of authority and subordinate groups with particular interests "conflicting directions and substances". Here we are dealing with another key concept in Dahrendorf's conflict theory, namely interests. The groups above and the groups below are defined by mutual interest. Dahrendorf maintains that the interest, which appears to be a psychological phenomenon, is essentially a large-scale phenomenon. The election of the village head is one of the activities in the administration of the village government. The election of village heads (Pilkades) is very prone to cause conflict, because it is in direct contact with the community. The simultaneous election of village heads in Blitar regency cannot be separated from the conflict which becomes a prolonged conflict. Variable conflicts include: (1) Candidates are only one till the deadline of registration, eventually his wife registers as a competitor. (2) Three villages resigned, one of candidates was sick and passed away, eventually competitors who are married couples also resigned. (3) Unelected candidate object and filed a lawsuit to the court. (4) Supporters create a sensation by releasing amounts to hundreds quintals of fish in rivers that affect people to hunt fish than election of village heads. (5) The dawn attack by handing out money to the public in secret to choose one of the candidates. 


\section{Factors Causing (pilkades) Simultaneous Election of Village Heads' Conflict in Blitar District}

The simultaneous election of village heads is a real face of democracy, because it is in direct contact with the community that is done jointly. Candidates are really elected directly by people who already know, even they are their relatives. The community itself is more enthusiastic in the election of the village head, than the legislative election. The existence of conflicts resulting from the simultaneous election of village heads in Blitar district is sourced to each candidate in obtaining support from the community in their respective villages. The background of the conflict of village head election simultaneously in Blitrar Regency are as follows: (1) The existence of community support to the village head incamband so that there is no rival candidate, (2) Wife of candidate nominates as competitor only for formality, (3) Complaints of dissatisfaction resulting from the election of the village head were triggered by the attitude of fanaticism, (4) Conflict of simultaneous village head election in Blitar Regency is ridden by other interests. Another interest is that there are people who do not like one of the candidates and want to drop one of the parties.

\section{Conclusion}

Based on the results of research and discussion from conflict of simultaneous village head election in Blitar Regency, it can be concluded that: Conflict in people's life must happen, it is reality of life, because of difference of opinion and interest. From these differences of opinion and interests, the causes of collisions cannot be minimized, thus spreading into social conflict. The conflict in Blitar district in the village head election is also due to the conflicting interest that is between each supporter who wants their candidate win. Without seeing what he does can hurt others even their relationship with his family is not good. Variable conflicts include: (1) A candidate is the only one till the deadline of registration, eventually his wife registers as a competitor. (2) one of candidates was sick and passed away, eventually competitors who are married couples also resigned (3) Unelected candidate object and filed a lawsuit to the court. (4) Supporters create a sensation by re- leasing amounts to hundreds quintals of fish in rivers that affect people to hunt fish than election of village heads. (5) The dawn attack by handing out money to the public in secret to choose one of the candidates.

\section{Suggestion}

After the researcher conducted research of conflict simultaneous Election of Head village in Blitar Regency, the suggestion as follows: (1) Blitar district people who have experience in village head election to be more responsible in choosing a leader. As a supporter do not hate other supporters, keep each other's sense of kinship, friendship, so that after the election of the village head there is no division within the community. (2) For the authorities in view of a case must really base on the truth of fact, (3) In the village head election to seek support should be in a sporty manner, do not drop another party.

\section{Reference}

Badan Kesatuan Bangsa, Politik, dan Perlindungan Masyarakat Kabupaten Blitar. (2013). Desa Mundur, Pilkades Serentak Hanya diikuti 153 Desa. (Online), (http:// www.blitarkab.go.id/-desa-mundurpilkades-serentak-hanya-diikuti-153-desa.)

Dahrendorf, R. (1986). Konflik dan Konflik dalam Masyarakt Indrustri. Terj. Ali Mandan. Jakarta: Rajawali.

Gean, P., \& Rubin, Jeffery. (2011). Teori Konflik Sosial. Yogyakarta: Pustaka Pelajar

Hendrastomo. (2009). Demokrasi dan Politik Pencitraan Perang Iklan Politik Menuju Demokratisasi Di Indonesia: Demokrasi dan Politik Pencitraan. Dimensia, 3(2):2.

Ikhwan, A.H. (2004). Akar Konflik Sepanjang Zaman Elaborasi Pemikiran Ibnu Khaldun. Yogyakarta: Pustaka Pelajar Offset.

Latief, S.S. (2000). Persaingan Calon Kepala Desa di Jawa. Jakarta: PT Raja Grafindo Persada.

Mustaghfiroh, A. (2012). Persepsi Masyarakat terhadap Kepala Desa sebagai Penggerak Politik. Disertasi tidak diterbitkan. Yogyakarta: Universitas Negeri Yogyakarta.

Ritzer, G., et all. (2008). Teori Sosiologi Modern. Jakarta: Prenada Media Grup. 
Journal Of Development Research , 2 (1), May 2018, Page 28-31

Rohyati, A., et all. (2006). Pilkada dan

Pengembangan Demokrasi Lokal.

Yogyakarta: KPU Provinsi DIY. 